\title{
Side effects of sugammadex use in pediatric patients
}

\author{
Pediatrik hastalarda sugammadeks kullanımının yan etkileri
}

\author{
Sinem Sarı ${ }^{1}$, Banu Taşdemir ${ }^{1}$, Sezen Sözkısacık ${ }^{2}$, Feray Gürsoy ${ }^{1}$
}

\begin{abstract}
Objective: It is accepted that sugammadex show its effects more rapidly than the other neuromuscular block antagonists in many studies, however especially in pediatric cases, it is seen that about its reliability and side effects are limited in some studies. In our retrospective study, we aimed to present our experiences on sugammadex in terms of its side effects in the pediatric cases in our hospital for a 1-year period.
\end{abstract}

Methods: The patient files and intraoperative anesthesia records, postoperative 24th hour and after postoperative 24th hour of the cases that underwent the application of sugammadex under general anesthesia in pediatric surgery operating room in a 1-year period were analyzed.

Results: Totally 46 patients received sugammadex; infants (28 days-23 months) $(n=24)$, children (2 years-11 years) $(n=16)$ and adolescent (11-17 years) $(n=6)$. None of the patients showed hypersensitivity and statistically significant side effects correlated to sugammadex.

Conclusion: We think that sugammadex may open new doors in pediatric patient group with its features. However, more documentation is needed about the safety in pediatric patient group, particularly in infants. J Clin Exp Invest 2013; 4 (3): 265-268

Key words: Sugammadex, pediatric patient, side effect

\section{INTRODUCTION}

Sugammadex is a new drug designed to eliminate the effects of steroid formed nondepolarizing muscle relaxants such as rocuronium, vecuronium by selectively binding them. The first phase I study that was performed with sugammadex in volunteers was published in 2005 [1]. It is accepted that its effect more rapidly than the other neuromuscular block antagonist agents with its mechanism of action in many performed studies during the period up to the present [2-5], however especially in pediatric cases, it is seen that the studies about its reliability and side effects are limited. Even though European

\section{ÖZET}

Amaç: Sugammadeks'in diğer nöromuskuler blok antagonisti ajanlardan daha hızlı etki gösterdiği yapılan çalışmalarla kabul edilmektedir fakat özellikle pediatrik olgularda güvenilirlik, yan etkileri ile ilgili yapılan çalışmaların sınırlı olduğu görülmektedir. Kliniğimizdeki pediatrik olgularda bir yıllık süredeki sugammadeks deneyimlerimizin yan etkileri bakımından olgu serisi olarak sunulması amaçlanmıştır.

Yöntemler: Bir yıllık sürede Tıp Fakültesi ameliyathanesi, çocuk cerrahisi odasında genel anestezi altında sugammadeks uygulanmış olguların dosyaları ve intraoperatif anestezi kayıtları, postoperatif 24 saat ve postoperatif 24 saat sonrası kayıtları incelendi.

Bulgular: İnfant (28 gün- 23 ay) $(n=24)$, çocuk (2 yas- 11 yas) $(n=16)$, adolesan (11- 17 yas) $(n=6)$ olmak üzere sugammadeks uygulanan toplam hasta sayısı 46 idi. Hastaların hiçbirisinde hipersensitivite bulgularına ve sugammadeks ile ilişkilendirilen istatistiksel anlamlı yan etkiye rastlanmadığı tespit edildi.

Sonuç: Sugammadeks'in sahip olduğu özellikleri ile pediatrik hasta grubunda yeni kapılar açabileceğini düşünmekteyiz. Fakat pediatrik hasta grubunda özellikle infantlarda güvenliği ile ilgili daha fazla dökümantasyona ihtiyaç vardır.

Anahtar kelimeler: Sugammadeks, pediatrik hasta, yan etki

Registration Authorities (EMEA) accepted Sugammadex on July 2008, the FDA (Food and Drug Administration, USA) seks more information about the hypersensitivity tests $[6,7]$. More pediatric recording studies and the documentation of sugammadex use in different clinical conditions will be important in terms of increasing our knowledge about the use of sugammadex.

For this reason, it is aimed that to present our experiences on sugammadex in terms of its side effects in the pediatric cases in our hospital for a 1 -year period in this retrospective study.

${ }^{1}$ Adnan Menderes University, Department of Anesthesiology and Reanimation, Aydın, Turkey

${ }^{2}$ Adnan Menderes University, Department of Pediatric Surgery, Aydın, Turkey

Correspondence: Sinem Sarı,

Adnan Menderes University, Medical Faculty, Department Anesthesiology and Reanimation Aydın, Turkey Email: sarisinem@yahoo.com Received: 22.03.2013, Accepted: 13.06.2013

Copyright (C) JCEI / Journal of Clinical and Experimental Investigations 2013, All rights reserved 


\section{METHODS}

After approval by the local ethics committee, the patient files and intraoperative anesthesia records of the cases that underwent sugammadex application under general anesthesia in ADU Medical Faculty pediatric surgery operating room in a 1-year period between November 2011 and November 2012 were analyzed. The patients were divided into 3 groups according to their ages; infant (28 days-23 months), child (2 years-11 years), adolescent (11-17 years). For all patients, the ASA score, body weight, operation time, extubation time, presence of complication, previous anesthesia experiences, presence or non-presence of comorbid diseases, if yes which diseases were obtained from the records. The side effects that the patients showed were examined intraoperative, acute postoperative (in 24 hours after the operation) and 24 hours after the operation. Side effects were questioned by telephoning the patients.

\section{RESULTS}

The demographic data and duration of the operations are shown in Table 1. Total number of patients who underwent sugammadex application was
46; infants (28 days- 23 months) $(n=24)$, children (2 years-11 years) $(n=16)$ and adolescent $(11-17$ years) $(n=6) .30 .4 \%$ of the patients went into operation electively, whereas $69.6 \%$ of them emergence (Table 2). The mean operation time was the longest in infant group (Table 1). It was seen that the cases received one dose of rocuronium for general anesthesia. It was seen that tracheal intubation was performed by giving the patient $0.6 \mathrm{mg} / \mathrm{kg}$ rocuronium and propofol and caudal analgesia or opioid analgesia was performed. All of the patients were in ASA 1-2 group. It was detected that the cases did not have neuromuscular diseases, renal dysfunction, malignant hyperthermia or a history of allergy. Extubation time of 12 patients in the infant group, 7 patients in the child group and 5 patients in the adolescent group were detected. The mean extubation time was $56.5,84.5$ and 77.4 seconds in the infant, child and adolescent group, respectively. When the patients were analyzed in terms of the side effects, it was seen that there was a significant difference between the groups in terms of the incidence of nausea, vomiting in postoperative 24 hours and surgical complication after postoperative 24 hours. None of the intraoperative and postoperative patients showed hypersensitivity findings (Tables 3-5).
Table 1. The demographic findings of the patients

\begin{tabular}{lccc}
\hline & $\begin{array}{c}\text { Infant } \\
(\mathrm{n}=24)\end{array}$ & $\begin{array}{c}\text { Child } \\
(\mathrm{n}=16)\end{array}$ & $\begin{array}{c}\text { Adolescent } \\
(\mathrm{n}=6)\end{array}$ \\
\hline Age & $11.0(2.2-12.0) \mathrm{mo}$ & $4.0(2.0-7.0) \mathrm{yrs}$ & $15.0(14.2-15.0) \mathrm{yrs}$ \\
Weight & $9.25(6.0-10.0)$ & $17.0(10.5-21.5)$ & $40.0(30.0-46.2)$ \\
(median, 25-75 percent) & $22 / 2$ & $12 / 4$ & $2 / 4$ \\
Gender (male/female) & 29.71 & 18.0 & 13.33 \\
Operation time (min) & & & \\
\hline
\end{tabular}

Table 2. Operation types according to the groups

\begin{tabular}{lccc}
\hline & $\begin{array}{c}\text { Infant } \\
(\mathrm{n}=24)\end{array}$ & $\begin{array}{c}\text { Child } \\
(\mathrm{n}=16)\end{array}$ & $\begin{array}{c}\text { Adolescent } \\
(\mathrm{n}=6)\end{array}$ \\
\hline Esophagoscopy & 4 & 11 & 4 \\
Umblicalhernia & 0 & 1 & 0 \\
Ileus & 1 & 1 & 0 \\
Anus surgery & 0 & 1 & 0 \\
Bronchoscopy & 7 & 2 & 0 \\
Cyscostopy & 1 & 0 & 0 \\
Pyeloplasty & 2 & 0 & 0 \\
Diagnostic laparotomy & 1 & 0 & 0 \\
Pyloromyotomy & 5 & 0 & 0 \\
Testicular torsion & 1 & 0 & 0 \\
Appendectomy & 0 & 0 & 2 \\
VUR & 1 & 0 & 0 \\
Undescended testis & 1 & 0 & 0 \\
\hline
\end{tabular}

Table 3. The distribution of intraoperative side effects according to the groups

\begin{tabular}{lccc}
\hline & $\begin{array}{c}\text { Infant } \\
(\mathrm{n}=24)\end{array}$ & $\begin{array}{c}\text { Child } \\
(\mathrm{n}=16)\end{array}$ & $\begin{array}{c}\text { Adolescent } \\
(\mathrm{n}=6)\end{array}$ \\
\hline $\begin{array}{l}\text { Bradycardia } \\
\begin{array}{l}\text { Hypersensitivity } \\
\text { (flushing, tachycardia) }\end{array}\end{array}$ & 0 & 0 & 0 \\
\hline
\end{tabular}


Table 4. The distribution of side effects in postop 24 hours according to the groups

\begin{tabular}{lccc}
\hline & $\begin{array}{c}\text { Infant } \\
(\mathrm{n}=24)\end{array}$ & $\begin{array}{c}\text { Child } \\
(\mathrm{n}=16)\end{array}$ & $\begin{array}{c}\text { Adolescent } \\
(\mathrm{n}=6)\end{array}$ \\
\hline Nausea, vomiting & 4 & 5 & 3 \\
Pain & 8 & 2 & 3 \\
Bradicardia & 0 & 0 & 0 \\
Spasm & 0 & 0 & 0 \\
Hypersensitivity & 0 & 0 & 0 \\
Urinary retention & 0 & 0 & 0 \\
Disuria & 4 & 1 & 0 \\
Hematuria & 4 & 0 & 0 \\
Hypoglycemia & 0 & 0 & 0 \\
Anemia & 0 & 0 & 0 \\
Enteritis & 0 & 0 & 0 \\
Pharyngitis & 0 & 0 & 0 \\
Surgical complication & 1 & 0 & 0 \\
\hline
\end{tabular}

Table 5. The distribution of side effects after postoperative 24 hours according to the groups

\begin{tabular}{lccc}
\hline & $\begin{array}{c}\text { Infant } \\
(\mathrm{n}=24)\end{array}$ & $\begin{array}{c}\text { Child } \\
(\mathrm{n}=16)\end{array}$ & $\begin{array}{c}\text { Adolescent } \\
(\mathrm{n}=6)\end{array}$ \\
\hline Weight gain & 0 & 0 & 0 \\
Anemia & 2 & 0 & 0 \\
Enteritis & 1 & 0 & 0 \\
Surgical complication & 9 & 0 & 2 \\
Constipation & 0 & 1 & 0 \\
Fever & 1 & 0 & 0 \\
\hline
\end{tabular}

\section{DISCUSSION}

Neuromuscular blockers are the main part of balanced anesthesia. The metabolism and elimination of neuromuscular blocker agents may change depending on the agent and it may be spontaneously slow. The most important indication of neuromuscular blocker agents is the presence of residual block. Nowadays, neuromuscular blocker antagonist agents are the most preferred group of anticholinesterases with their features [1].

Anticholinesterases do not only inhibit the acetylcholinesterase in the nicotinic receptors at the neuromuscular junction. They cause bradycardia, hypotension, salivation, an increase in gastrointestinal motility and bronchospasm with muscarinic receptor blockage. For this reason they have to be administered with antimuscarinic agents such as atropine, glycopirrolate [6]. Moreover, because they may be insufficient in deep block and residual block and they may cause fasciculations, the interest in the new agent sugammadex has increased $[1,8]$.

Sugammadex is completely different from the anticholinesterases. It effects independently from acetylcholin concentration and nicotinic or muscarinic receptors. Sugammadex, being particularly effective on the steroid formed nondepolarizing muscle relaxants rocuronium and vecuronium, is an agent that is in cyclodextrin shape and the first selective steroid formed nondepolarizing muscle relaxant binder. By binding to rocuronium, sugammadex decreases the amount of drug circulating freely in plasma and in the nicotinic receptors [9]. For this reason, the side effects that are seen with anticholinesterases are not expected with sugammadex [6].

Studies that were performed about sugammadex are seen in patients diagnosed with terminal phase renal failure [10-12], cardiac disease [13], pulmonary disease [14]. It is suggested that sugammadex can be used in these patients more safely the results of these studies. However, when these studies are examined, it is seen that the patient number is too low and the performed studies do not include pediatric patient group.

Infants, children and adults should be evaluated differently because the pharmacokinetic and pharmacodynamic profiles of NMBA's are different depending on the ages [15]. The use of muscle relaxants in infants are more effective than in children and adults [6]. For instance, rocuronium's duration is much longer in infants when compared to the children and its potency is higher in infants than children and adults [15]. Residual paralysis in children occurs less often than adults [8]. Infants are more sensitive to nondepolarizing muscle relaxants and the required concentration of muscle relaxants for neonates and infants is less than the amount for the older children and adults. This situation is also important for the muscle relaxant to be reversed [6].

The first pediatric sugammadex studies showed that $2 \mathrm{mg} / \mathrm{kg}$ sugammadex is enough to reversed medium neuromuscular blockage with rocuronium in infants, children and adolescents. The required duration for the TOF rate to be $90 \%$ in children, adolescents and adults is reported as 1.2, 1.1 and 1.2 minutes respectively [6]. Even though our observations in our clinic are supportive of the studies that are performed in terms of the duration of effect, we could not reach to the TOF rates of all patients be- 
cause neuromuscular monitorization was not routinely performed.

In a study that Plaud et al performed, sugammadex' different doses and placebo were compared in 8 infants ( 28 days-23 months), 24 children (2-11 years), 31 adolescents as rocuronium administered pediatric patients. 1 infant, 5 children and 6 adolescent patients received $2 \mathrm{mg} / \mathrm{kg}$ sugammadex whereas 2 infants, 4 children, 5 adolescent patients received placebo. Of all the patients who received sugammadex, in 1 infant patient fever and nasopharyngitis; in 1 of 5 children patients vomiting, in 2 of them pain related to surgery; in 3 of 6 adolescent patients surgical pain, and in 3 of them vomiting were observed. In the group that received placebo, vomiting, rhinitis, fever and complication related to procedure in 1 patient; vomiting in 2 children patients, pain related to surgery in 1 child patient, pain related to surgery in 3 adolescent patients, vomiting in 3 patients and nausea in 1 patient were observed. The seen side effects are not correlated to sugammadex. They reported that sugammadex use in infant, child and adolescent groups is effective and reliable and that they did not find any hypersensitivity findings with $2 \mathrm{mg} / \mathrm{kg}$ sugammadex [15]. We found hypersensitivity findings in none of our patients. The most common side effect in our patients was acute postoperative nausea, vomiting and pain related to the surgery. We thought that the side effects we observed were related to the type of surgery. However, we could not relate these side effects with sugammadex because we did not have a placebo group.

In conclusion, we think that sugammadex may open new doors in pediatric patient group with its features. However, more documentation is needed about the safety in pediatric patient group, particularly in infants.

\section{REFERENCES}

1. Mirakhur R. K. Sugammadex in clinical practice. Anaesthesia 2009;64:45-54.

2. Chambers D, Paulden M, Paton F, et al. Sugammadex for reversal of neuromuscular block after rapid se- quence intubation: a systematic review and economic assessment. Br J Anaesthesia 2010;105:568-575.

3. Sacan O, White PF, Tufanogullari B, et al. Sugammadex reversal of rocuronium-induced neuromuscular blockade: a comparison with neostigmine-glycopyrrolate and edrophonium-atropine. AnesthAnalg 2007;104:569-574.

4. Welliver M, Cheek D. An update on sugammadex sodium. AANA Journal 2009;77:219-228.

5. de Boer HD, van Esmond J, Booij LH, Driessen JJ.Reversal of rocuronium-induced profound neuromuscular block by sugammadex in Duchenne muscular dystrophy. Paediatr Anaesth 2009;19:1226-1228.

6. Meretoja OA. Neuromuscular block and current treatment strategies for its reversal in children. Paediatr Anaesth 2010;20:591-604.

7. Glinka L, Onichimowski D, SieniutaP, Korecki A. Sugammadex-two years in clinical practice. Anaesthesiol Intensive Therapy 2010;3:139-143.

8. Della Rocca G, Pompei L. A novel approach to reversal of neuromuscular blockade. Minerva anestesiol 2009;75:349-51.

9. Tanrıkulu N, Çelik S, Kırbaş A, et al. Sugammadex reversal of neuromuscular blockade forthy mectomyin a patient with myasthenia gravis. Anatol J Clin Investig 2012;6:48-50.

10. Staals LM, Snoeck MM, Driessen JJ, et al. Multicentre, parallel-group, comparative trial evaluating the efficacy and safety of sugammadex in patients with end-stage renal failure or normal renal function. $\mathrm{Br} \mathrm{J}$ Anaesth 2008;101:492-497.

11. Robertson EN, Driessen JJ, Booij LHDJ. Pharmacokinetics and pharmacodynamics of rocuronium in patients with and without renal failure. Eur $\mathrm{J}$ Anaesthesiol 2005;22:4-10.

12. Staals LM, Snoek MM, Flockton EA, et al. The efficacy of sugammadex in subjects with impaired renal function [abstract]. Eur J Anaesthesiol 2007;24:122-123.

13. Shah RR. Drugs, QTc interval prolongation and final ICH E14 guideline: an important milestone with challenges ahead. Drug Safety 2005;28:1009-1028.

14. Amao R, Zornow MH, Cowan RM, et al. Use of sugammadex in patients with a history of pulmonary disease. J Clin Anesth 2012;24:289-297.

15. Plaud B, Meretoja O, Hofmockel R, et al. Reversal of rocuronium-induced neuromuscular blockade with sugammadex in pediatric and adult surgical patients. Anesthesiology 2009;110:284-294. 